Article

\title{
Did the Federal Agriculture Improvement and Reform Act of 1996 Affect Farmland Values?
}

\author{
Ashok K. Mishra ${ }^{1}{ }^{*}$, Grigorios T. Livanis ${ }^{2}$ and Charles B. Moss ${ }^{3}$ \\ 1 LSU AgCenter, Department of Agricultural Economics and Agribusiness, Louisiana State \\ University, Baton Rouge, LA 70803, USA \\ 2 International Business and Strategy Group, Northeastern University, Boston, MA 02115, USA; \\ E-Mail: g.livanis@neu.edu \\ 3 Department of Food and Resource Economics, University of Florida, Gainesville, FL 32611, USA; \\ E-Mail: cbmoss@ufl.edu \\ * Author to whom correspondence should be addressed; E-Mail: amishra@1su.edu.
}

Received: 4 March 2011; in revised form: 13 March 2011 / Accepted: 14 March 2011 /

Published: 17 March 2011

\begin{abstract}
Farmland values are affected by numerous factors, including farm policy, shifts in demand for agricultural output both foreign and domestic, monetary policy and urban pressure. In this study we use an information measure to examine whether the shift toward a more market-oriented policy in 1996 changed the relationship between farmland values and government payments. The results indicated that the shift in agricultural policy resulted in significant shift in this relationship.
\end{abstract}

Keywords: agricultural policy; entropy; farmland value; government payments

\section{Introduction}

In this study we use an information measure to examine whether the shift toward a more market-oriented policy in 1996 changed the relationship between farmland values and government payments [1]. The Federal Agricultural Improvement and Reform (FAIR) Act of 1996 represented a major market oriented shift in price support policies which started with the Agricultural Adjustment Act of 1933 [2]. Specifically, the New Deal farm bills included a number of policy instruments which linked farm production decisions to policy variables. For example, the Agricultural Adjustment Act of 
1938 included acreage allotments and marketing quotas. Farmland is the most important asset in the farm business and in the farm household investment portfolio. Nationally, in 2009 real estate accounted for more than three-fourths of total farm business assets. On the other hand, the average investment portfolio of a typical farm household was worth $\$ 895,756$ in 2009 . Of this worth, real estate comprised 75 percent of its value. For landowners who operate farms, the value of land as a business asset helps to secure operating and expansion loans. For landowners that do not operate farms, the income from renting farmland often represents an important component of household income. Hence, farmland occupies a uniquely important role in the performance of the agricultural sector because of its dominance on agriculture's balance sheet. Therefore, any changes in the farm program payments will affect farmland values. Further, any changes in farmland values can have significant consequences for the sector solvency and, hence its financial viability.

The issue of farmland valuation for agricultural purposes is a perennial topic of interest for policymakers and farmers. Federal farm policy is a direct contributor to farmland value appreciation. Economists have understood for some time that the value of farm program payments are capitalized into land values as these payments become a component of expected future returns [3]. Over time significant changes in agricultural policy were introduced which brought about more production choice. The Agricultural and Consumer Protection Act of 1973 introduced target prices for wheat, feed grains, and upland cotton. The Agricultural and Food Act of 1981 eliminated the system of allotments, replacing them with base acreages. In a sense, the market orientation of agricultural policies reached a zenith with the enactment of FAIR Act of 1996. The FAIR Act implemented Agricultural Market Transition Assistance (AMTA) payments based on historical yields on base acreages.

\section{Literature Review}

Much of the rise in farmland value is attributed to farm programs, under which farmers received government payments that are capitalized in the farmland [3-11]. The capitalization of government programs into land prices has also been discussed in the literature [12-16]. Tweeten et al. [14] concluded that pressures to increase farm size and the capitalized benefits of farm programs could explain $52 \%$ of the variation in land prices. Traill [17] notes that capitalizing the full benefits of a support program will not affect net farm income in the short-run. Clark et al. [18] also found that government subsidies as well as market-based income were capitalized into land values for Saskatchewan using a cointegration approach. In another study, Just et al. [19] developed a structural model of farmland prices based on 1963-1986 data, which included the multi-dimensional effects of inflation on capital erosion, saving-return erosion, and real debt reduction as well as the effects of changes in the opportunity costs of capital. Their results showed that inflation and changes in real return on capital were major explanatory factors in farmland price swings. In addition, Just et al. [19] estimated that government payments account for approximately 15 to $20 \%$ of the capitalized value of land in U.S., but only a small part of the fluctuations. Moss et al. [20] used Bayesian vector analysis to investigate the effect of government payments on real agricultural assets values. Their analysis focused on the informational content of government payments. The authors concluded that in the short-run, government payments and asset values were negatively correlated. However, in the long-run, government payments had little positive effect on real asset values. Using a different scenario, 
Featherstone et al. [21] estimated that a move to a free market from the 1985 farm programs would reduce land prices in the U.S. by approximately $13 \%$ in five years.

A plethora of literature on the factors affecting farmland values has been published and the empirical relationship is well recognized in the agricultural economics literature. These include the income capitalization model [22-24] and hedonic models [25-27]. Analysis included empirical application to macro economic variables like interest rate and inflation [19], specific farm programs and crops [18,22,28-32], farm program bases [6,29,33] and historical farm program payments [11,34] using historical data, (1938-2006). Falk [34] studied the plausibility of the constant expected returns version of the present value model as a tenable explanation of farmland prices. The research by Melichar [16] and others lead to the acceptance of the relationship between cash rents and land values.

Recent literature on farmland values has focused on the effect of government payments. In the last two decades, studies of government payment impacts have also included those of specific crops and specific programs $[28,30]$. Payments linked to program bases and resulting impacts on agricultural land values were examined by [5]. The effect of eliminating government payments on agricultural land values was analyzed by [8]. Their county-level, cross-sectional examination of government payment effects on land values used data from the U.S. Department of Agriculture's 2000 Agricultural Resource Management Survey (ARMS). Based on their analysis of eight U.S. agriculture production regions, eliminating government programs would reduce agricultural land values by $12 \%$ to $69 \%$. Weersink et al. [9] and [10] found that government payments increased agricultural land values. Goodwin, Mishra, and Ortalo-Magne [29] and Lence et al. [35] concluded that government payments positively affected cash rents.

Shaik et al. [11] cited problems with earlier studies caused by identification issues introduced by counter-cyclical farm program payments and farm returns. The issue results from the misuse of farm program payments as exogenous variables in land valuation models. The authors [11] concluded that farm program payments and crop receipts represented $30 \%$ and $70 \%$ of agricultural land values, respectively. Furthermore, they found that the contribution of farm program payments to land values declined from a high of $30 \%$ to $40 \%$ during the 1938 to 1980 period to about $15 \%$ to $20 \%$ in subsequent farm bill periods. Shaik [33] found similar results using four alternative panel estimators. Shaik et al. [36] using a dynamic framework and data from 1933-2006 found payments have a positive direct in the short run and a positive indirect impact (via farm returns) in the long run on farmland values. Finally, Goodwin et al. [37] using farm-level data and expectations modeling approach investigated the impact of farm programs payments, along with different types of farm programs payments, on farmland values, cash and share rents. The authors concluded that farm programs payments have significant impact on farmland values and rental rates. Further, [38] point out that ignoring expectations and differences across payments types makes some existing work questionable.

\section{Model}

Most empirical evaluations of the determinants of land values adopt a present value model, where the value of a productive asset is given by the capitalized values of current and expected future streams 
of net income generated by the asset. Under standard assumptions, farmland values are determined by the present value of future rents:

$$
V_{t}=\sum_{i=1}^{\infty} \frac{\mathrm{E}\left[C F_{t+i} \mid \Omega_{t}\right]}{\prod_{j=1}^{i}\left(1+r_{t+j}\right)}
$$

where $V_{t}$ is the value of farmland, $\mathrm{E}\left[C F_{t+i} \mid \Omega_{t}\right]$ is the expected cash flow from farmland (typically the Ricardian rent defined as the excess of returns over the variable factors of production), and $r_{t}$ is the discount rate parameterized as the weighted average cost of capital. Expanding this formulation to consider government payments:

$$
V_{t}=\sum_{i=1}^{\infty} \frac{\mathrm{E}\left[C F_{t+i}^{M} \mid \Omega_{t}\right]+\mathrm{E}\left[G P_{t+i} \mid \Omega_{t}\right]}{\prod_{j=1}^{i}\left(1+r_{t+j}\right)}
$$

where $\mathrm{E}\left[C F_{t+i}^{M} \mid \Omega_{t}\right]$ are the expected cash flow from the market, and $\mathrm{E}\left[G P_{t+i} \mid \Omega_{t}\right]$ are the cash inflows from government payments. The conjecture (hypothesis) is that the passage of FAIR represented a structural break in the time series of $\mathrm{E}\left[G P_{t+i} \mid \Omega_{t}\right]$ and possibly affects $\mathrm{E}\left[C F_{t+i}^{M} \mid \Omega\right]$.

\section{Data and Methods}

This study uses the United States Department of Agriculture, Economic Research Service net valued added data for government payments and farm income. In addition, we use the United States Department of Agriculture's data on total farmland values (data on values per acre were taken from various issues of [39] and the acreage in each state is taken from the [38]).

The information measure applied is based on [1] measure of income inequality. The information approach assumes that the two sets of probabilities embody the effect of a signal. Our formulation allows for a regional decomposition of the information in farmland value changes. The informational measure is then applied to farmland values in the United States. Specifically, we define the informational content of government payments in explaining farmland values as:

$$
I_{t}=\sum_{i=1}^{n} p_{i t} \ln \left(\frac{p_{i t}}{q_{i t}}\right)
$$

where $p_{i t}$ is the $i^{\text {th }}$ state's share of total farmland value at time $t$ and $q_{i t}$ is the $i^{\text {th }}$ state's share of total government payments to agriculture. As described by Theil et al. [40], the informational measure in Equation (3) measures the difference in information between a prior distribution, $q_{i}$ (the probability distribution of the event, E, before the signal arrives) and a posterior distribution, $p_{i}$ (the probability distribution of the event, $\mathrm{E}$, after the signal has been observed). If the posterior information is the same as the prior distribution there is no information in the signal. As $I_{t} \rightarrow 0$ the government payments perfectly predict the distribution of farmland values across states while as $I_{t} \rightarrow \infty$ government payments contain little information regarding the distribution of farmland values. Following Theil's [1] general formulation of the information measue of inequality, we define the regional inequality for information measure in Equation (1) as: 


$$
I_{g t}=\sum_{i \in g}\left(\frac{p_{i t}}{\sum_{j \in g} p_{j t}}\right) \ln \left(\frac{\frac{p_{i t}}{\sum_{j \in g} p_{j t}}}{\frac{q_{i t}}{\sum_{j \in g} q_{j t}}}\right) .
$$

where $I_{g t}$ is the regional inequality in government payments within region $g$. Based on these grouping, we then define information inequality across regions as:

$$
I_{R t}=\sum_{g}\left(\sum_{i \in g} p_{i t}\right) \ln \left(\frac{\sum_{i \in g} p_{i t}}{\sum_{i \in g} q_{i t}}\right) .
$$

The average inequality across regions is then defined as:

$$
\bar{I}_{R t}=\sum_{g}\left(\sum_{i \in g} p_{i t}\right) I_{g t} .
$$

The total inequality in Equation (1) can the be expressed as the sum of the results of Equations (5) and (6).

$$
I=\bar{I}_{R t}+I_{R t}
$$

To test for the significance of the changes in agricultural payments due to FAIR we estimate a simple model using ordinary least squares:

$$
I_{t}=\alpha_{0}+\alpha_{1} t+\alpha_{2} D_{t}+\alpha_{3} I P R_{t}+\varepsilon_{t}
$$

where $t$ is a time trend, $D_{t}$ is a dummy variable which is equal to 0 if $t<1996$ and equal to 1 if $t \geq 1996, I P R_{t}$ is the index of prices received by farmers. The maintained hypothesis is that FAIR had no effect on the relationship between farmland values and government payments, or $H_{0}: \alpha_{2}=0$. The alternative hypothesis is that FAIR changed the relationship between farmland values and government payments $H_{0}: \alpha_{2} \neq 0$. Through the analysis [Equation (8)] we investigate if the implementation of FAIR Act has significantly affected the relationship between the share of farmland values and the share of government payments for all US, between, and across regions.

\section{Results}

In order to analyze the effect of FAIR on the relationship between government payments and farmland values we start with an analysis of the ten Econonomic Research Service regions. These regions aggregate states by agronomic characteristics. Hence, the same portfolio of crops is typically produced in each region. After analyzing the data for each region, we then analyze the change in information across regions.

\subsection{Regional Inequalities}

The values of the regional inequalities for each of the ten Economic Research Regions are presented in Table 1. Over time the inequality is highest for the Northeast, Southeast, and Mountain regions. 
Arguably, the size of the inequality in these regions may be explained by the relative lack of program crops. In addition, the inequality appears to be highest for the period 1975 through 1980, roughly corresponding with the boom/bust period for farmland in the late 1970s through the financial crisis in the mid 1980s. During that period, the inequality is relatively higher for the Lake States, Corn Belt and Northern Plains.

Table 1. Regional inequality $(\times 1,000)$ between land values and government payments.

\begin{tabular}{|c|c|c|c|c|c|c|c|c|c|c|}
\hline Year & Northeast & $\begin{array}{c}\text { Lake } \\
\text { States }\end{array}$ & $\begin{array}{c}\text { Corn } \\
\text { Belt }\end{array}$ & $\begin{array}{c}\text { Northern } \\
\text { Plains }\end{array}$ & Appalachia & Southeast & Delta & $\begin{array}{l}\text { Southern } \\
\text { Plains }\end{array}$ & Mountain & $\begin{array}{l}\text { Pacific } \\
\text { States }\end{array}$ \\
\hline 1950 & 75.3 & 9.4 & 46.2 & 20.1 & 3.7 & 86.6 & 61.7 & 5.2 & 104.2 & 2.2 \\
\hline 1951 & 73.1 & 31.7 & 44.8 & 48.7 & 2.0 & 57.5 & 68.9 & 16.8 & 66.7 & 3.0 \\
\hline 1952 & 51.9 & 25.2 & 93.2 & 35.7 & 9.3 & 74.2 & 64.1 & 25.5 & 79.7 & 12.9 \\
\hline 1953 & 63.9 & 2.0 & 57.9 & 51.4 & 39.0 & 21.5 & 23.0 & 37.7 & 181.7 & 13.7 \\
\hline 1954 & 51.9 & 1.3 & 62.3 & 23.9 & 37.9 & 73.3 & 74.6 & 1.3 & 89.2 & 24.1 \\
\hline 1955 & 100.0 & 12.1 & 25.0 & 26.3 & 3.0 & 151.2 & 70.3 & 4.6 & 146.2 & 6.6 \\
\hline 1956 & 42.1 & 13.8 & 75.5 & 126.7 & 65.9 & 107.7 & 52.5 & 0.6 & 131.3 & 14.6 \\
\hline 1957 & 24.1 & 7.8 & 65.5 & 12.0 & 28.3 & 333.4 & 1.7 & 5.1 & 90.9 & 35.0 \\
\hline 1958 & 21.0 & 6.0 & 82.1 & 27.3 & 64.2 & 519.0 & 4.2 & 4.0 & 99.0 & 24.9 \\
\hline 1959 & 102.6 & 4.7 & \begin{tabular}{|l|}
88.7 \\
\end{tabular} & 99.0 & 60.9 & 277.3 & 1.7 & 1.6 & 187.2 & 81.2 \\
\hline 1960 & 123.0 & 0.9 & 82.3 & 125.9 & 34.4 & 284.8 & 7.2 & 9.1 & 249.8 & 107.8 \\
\hline 1961 & 129.1 & 7.0 & 26.8 & 4.5 & 25.0 & 285.3 & 2.7 & 1.3 & 146.7 & 104.5 \\
\hline 1962 & 118.4 & 7.6 & 31.1 & 11.6 & 15.4 & 312.1 & 9.8 & 14.6 & 162.1 & 206.2 \\
\hline 1963 & 110.6 & 24.7 & 30.3 & 13.0 & 18.7 & 239.8 & 12.5 & 12.2 & 176.7 & 132.2 \\
\hline 1964 & 107.1 & 35.2 & 51.5 & 10.9 & 19.6 & 267.9 & 35.3 & 12.1 & 211.1 & 308.4 \\
\hline 1965 & 97.8 & 24.2 & 37.2 & 6.7 & 25.9 & 250.5 & 33.9 & 9.9 & 173.5 & 316.9 \\
\hline 1966 & 110.0 & 19.4 & 55.9 & 16.0 & 69.1 & 404.3 & 56.8 & 2.6 & 41.5 & 89.1 \\
\hline 1967 & 98.3 & 13.4 & 46.2 & 32.3 & 82.9 & 387.3 & 72.9 & 3.2 & 44.9 & 71.1 \\
\hline 1968 & 95.9 & 20.9 & 27.0 & 12.2 & 68.8 & 328.3 & 59.2 & 5.9 & 34.3 & 79.3 \\
\hline 1969 & 103.7 & 38.4 & 16.8 & 15.5 & 62.2 & 304.1 & 63.1 & 5.8 & 41.6 & 51.4 \\
\hline 1970 & 85.8 & 38.7 & 23.0 & 17.0 & 63.0 & 327.0 & 72.5 & 9.4 & 45.6 & 40.0 \\
\hline 1971 & 99.6 & 51.8 & 10.0 & 17.1 & 70.5 & 303.3 & 69.8 & 4.9 & 53.0 & 50.0 \\
\hline 1972 & 105.3 & 68.9 & 20.3 & 26.1 & 55.5 & 279.3 & 83.6 & 5.5 & 52.9 & 42.5 \\
\hline 1973 & 106.3 & 54.1 & 18.4 & 19.8 & 81.9 & 252.1 & 69.7 & 21.5 & 59.3 & 20.6 \\
\hline 1974 & 143.6 & 0.1 & 10.8 & 155.5 & 15.3 & 7.0 & 65.9 & 17.1 & 82.5 & 47.9 \\
\hline 1975 & 153.7 & 17.7 & 79.7 & 49.2 & 65.8 & 32.9 & 21.3 & 62.3 & 53.2 & 26.1 \\
\hline 1976 & 123.2 & 37.4 & 26.4 & 220.5 & 27.9 & 169.4 & 17.6 & 5.5 & 89.3 & 26.0 \\
\hline 1977 & 102.0 & 37.8 & 51.1 & 83.4 & 97.6 & 127.9 & 35.7 & 22.7 & 160.0 & 65.5 \\
\hline 1978 & 201.2 & 56.6 & 42.2 & 21.1 & 113.5 & 330.1 & 31.9 & 0.2 & 163.7 & 173.4 \\
\hline 1979 & 281.5 & 26.7 & 88.1 & 16.3 & 8.6 & 190.5 & 38.6 & 63.1 & 82.2 & 14.1 \\
\hline 1980 & 106.6 & 35.8 & 30.3 & 65.5 & 38.0 & 306.6 & 16.6 & 60.1 & 264.4 & 87.5 \\
\hline 1981 & 86.3 & 80.2 & 64.5 & 88.0 & 14.0 & 238.7 & 60.4 & 0.5 & 216.0 & 341.5 \\
\hline 1982 & 202.1 & 57.0 & 36.9 & 15.9 & 81.4 & 369.6 & 4.4 & 21.6 & 117.4 & 61.1 \\
\hline 1983 & 158.9 & 54.0 & 37.5 & 16.9 & 39.9 & 497.2 & 20.9 & 0.0 & 138.2 & 30.3 \\
\hline 1984 & 74.4 & 8.3 & 19.0 & 16.6 & 26.0 & 167.4 & 18.6 & 10.2 & 108.0 & 44.0 \\
\hline 1985 & 111.1 & 53.0 & 51.2 & 18.4 & 39.1 & 216.3 & 26.1 & 8.9 & 125.4 & 40.1 \\
\hline 1986 & 115.4 & 65.9 & 66.3 & 10.6 & 34.7 & 377.1 & 33.1 & 32.0 & 179.8 & 115.9 \\
\hline
\end{tabular}


Table 1. Cont.

\begin{tabular}{|c|c|c|c|c|c|c|c|c|c|c|}
\hline Year & Northeast & $\begin{array}{c}\text { Lake } \\
\text { States }\end{array}$ & $\begin{array}{c}\text { Corn } \\
\text { Belt }\end{array}$ & $\begin{array}{c}\text { Northern } \\
\text { Plains }\end{array}$ & Appalachia & Southeast & Delta & $\begin{array}{c}\text { Southern } \\
\text { Plains }\end{array}$ & Mountain & $\begin{array}{c}\text { Pacific } \\
\text { States }\end{array}$ \\
\hline 1987 & 147.1 & 67.6 & 80.0 & 7.6 & 37.7 & 476.1 & 10.4 & 1.8 & 202.0 & 73.7 \\
1988 & 170.1 & 38.6 & 54.5 & 6.1 & 45.4 & 495.0 & 5.2 & 1.2 & 185.8 & 74.9 \\
1989 & 127.5 & 10.3 & 27.8 & 15.5 & 102.2 & 399.8 & 3.6 & 5.9 & 119.3 & 15.2 \\
1990 & 137.6 & 22.8 & 32.9 & 25.5 & 97.4 & 339.9 & 9.8 & 7.6 & 178.9 & 141.4 \\
1991 & 202.0 & 27.6 & 34.1 & 36.3 & 74.6 & 225.7 & 15.2 & 16.4 & 211.0 & 142.8 \\
1992 & 92.0 & 14.3 & 32.4 & 22.1 & 127.9 & 301.5 & 2.0 & 2.8 & 128.7 & 37.4 \\
1993 & 229.4 & 23.3 & 44.7 & 2.9 & 113.4 & 151.5 & 8.0 & 0.9 & 107.5 & 27.7 \\
1994 & 133.3 & 82.0 & 18.5 & 48.1 & 74.2 & 179.0 & 0.0 & 0.4 & 201.8 & 54.1 \\
1995 & 162.8 & 26.3 & 54.0 & 2.3 & 45.8 & 45.4 & 49.4 & 0.2 & 560.1 & 32.7 \\
1996 & 203.8 & 19.7 & 21.2 & 22.2 & 68.2 & 345.4 & 7.3 & 2.5 & 260.0 & 41.0 \\
1997 & 207.7 & 26.4 & 25.3 & 9.8 & 67.8 & 374.3 & 2.2 & 2.6 & 317.7 & 75.8 \\
1998 & 229.3 & 52.6 & 25.3 & 7.9 & 86.3 & 418.8 & 2.3 & 1.6 & 330.5 & 93.5 \\
1999 & 160.4 & 51.7 & 23.5 & 6.0 & 72.7 & 284.7 & 6.1 & 0.4 & 339.7 & 32.4 \\
2000 & 120.6 & 63.4 & 28.1 & 23.1 & 79.2 & 198.4 & 14.3 & 0.5 & 341.0 & 52.5 \\
2001 & 158.3 & 81.6 & 20.9 & 16.1 & 100.7 & 234.4 & 22.9 & 2.2 & 303.4 & 35.8 \\
2002 & 279.1 & 12.2 & 12.5 & 14.7 & 97.5 & 426.8 & 4.9 & 0.7 & 226.5 & 30.4 \\
2003 & 161.3 & 30.5 & 14.7 & 24.6 & 70.8 & 207.4 & 13.6 & 0.8 & 181.0 & 24.1 \\
2004 & 127.0 & 50.5 & 48.1 & 6.1 & 89.2 & 20.5 & 11.2 & 3.0 & 247.6 & 33.1 \\
2005 & 94.4 & 50.6 & 34.9 & 8.3 & 202.0 & 61.9 & 59.0 & 15.9 & 288.4 & 24.2 \\
2006 & 113.7 & 22.4 & 12.9 & 6.6 & 167.4 & 219.1 & 30.8 & 6.4 & 224.1 & 31.7 \\
2007 & 100.3 & 40.8 & 9.2 & 19.1 & 180.3 & 188.1 & 31.2 & 1.2 & 201.0 & 39.6 \\
2008 & 59.5 & 33.7 & 14.6 & 33.9 & 165.2 & 125.7 & 5.2 & 6.2 & 267.9 & 61.5 \\
2009 & 129.7 & 11.3 & 14.7 & 44.4 & 150.8 & 291.3 & 15.2 & 3.2 & 220.3 & 26.4 \\
\hline
\end{tabular}

Figure 1, a box and whisker graph, shows the inequality measure over time and across regions. The graph shows changes in the quantile range over time. The interquantile range increases during the period 1960 through 1965 and then again after 1975. This later increase corresponds with the introduction of a more market oriented agricultural policies, providing support for the specification in Equation 8.

Table 2 presents the sample statistics for the regional inequalities along with the statistics for the pre-FAIR period (i.e., 1950 through 1995) and the post-FAIR period (i.e., 1996 through 2009). These sample statistics confirm the results from Table 1. The average inequality is highest for the entire sample for the Southeast region followed by the Mountain and then the Northeast regions. Examining the differences in the mean and standard deviation across each subsample, there appears to be significant changes in the inequality for the Corn Belt going from a mean 67.4 and standard deviation of 50.7 for the pre-FAIR period to a mean of 21.9 and standard deviation of 10.4 in the post-FAIR period. In the Northern Plains, the mean declines from 37.9 to 17.3 and the standard deviation declines from 44.6 to 11.5. In the Southern Plains the mean falls from 12.2 to 3.4 and the standard deviation falls from 15.9 to 4.1 , and in the Pacific states the mean falls from 76.3 to 43.0 and the standard deviation falls from 80.3 to 20.8 . On the other hand, the mean of the inequality increases from 50.6 in the pre-FAIR period to 114.2 in the post-FAIR period and the Mountain region where the mean 
inequality increases from 137.9 to 267.8 . Thus, the overall sample statistics support a general change in the relationship between government payments and farmland values.

Figure 1. Inequality measure over time across regions.

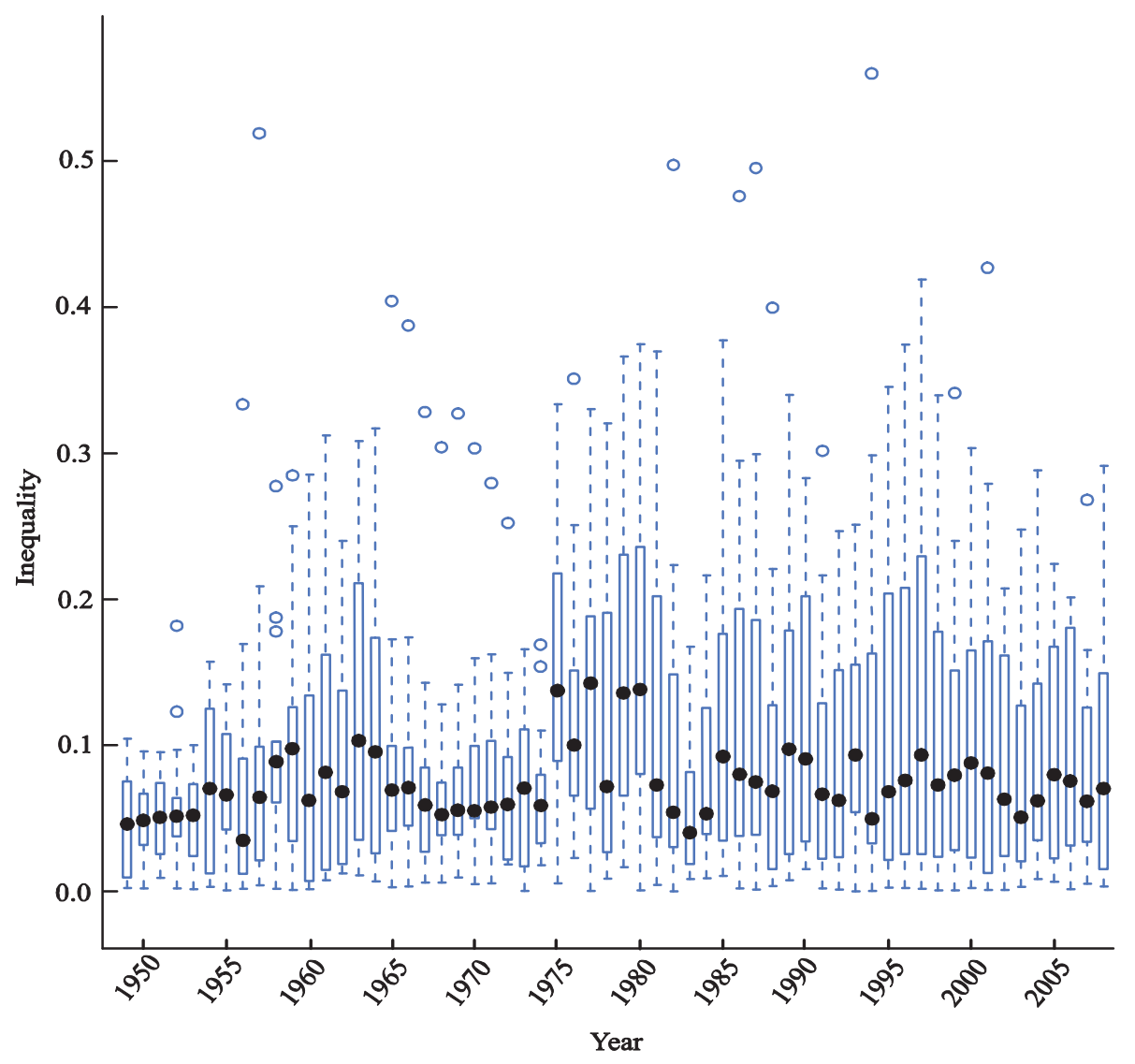

The bottom of Table 2 presents the ordinary least squares estimates (with the standard deviations and confidence levels estimated using a jackknife procedure [41,42] to correct for the possibility of non-normaility and hetroscedasticity in the data) of the model presented in Equation (8). The results for the Lake States, Corn Belt, Southern Plains, Mountain, and Pacific regions reject the null hypothesis of no structural shift. For the Lake States, Corn Belt, and Southern Plains indicate that the shift to FAIR is associated with a reduction in the information inequality. Thus, after the introduction of FAIR the farmland values in these regions were distributed more like the direct government payments. Results from this study are consistent with the findings in recent literature [36,37]. This is not the case with the Mountain region where the distribution of farmland values became less similar to the distribution of direct government payments.

The results also indicate that the trend variable is statistically significant and positive for the Northeast, Lake States, Corn Belt, Appalachia, and Southern Plains, and statistically significant and negative for the Southeast. In addition, the relative index in prices received is significant and positive for the Corn Belt, Northern Plains, and Southern Plains, and statistically significant and negative for the Southeast region. 
Table 2. Analysis of regional inequality between land values and government payments.

\begin{tabular}{|c|c|c|c|c|c|c|c|c|c|c|}
\hline & Northeast & $\begin{array}{c}\text { Lake } \\
\text { States }\end{array}$ & Corn Belt & $\begin{array}{c}\text { Northern } \\
\text { Plains }\end{array}$ & Appalachia & Southeast & Delta & $\begin{array}{c}\text { Southern } \\
\text { Plains }\end{array}$ & Mountain & $\begin{array}{l}\text { Pacific } \\
\text { States }\end{array}$ \\
\hline \multicolumn{11}{|c|}{ Full Sample } \\
\hline Min & 21.0 & 0.1 & 9.2 & 2.3 & 2.0 & 7.0 & 0.0 & 0.0 & 34.3 & 2.2 \\
\hline Quartile 1 & 97.3 & 13.1 & 24.9 & 11.9 & 32.9 & 163.4 & 7.3 & 1.5 & 90.5 & 26.3 \\
\hline Median & 112.4 & 26.6 & 41.1 & 18.8 & 65.0 & 260.0 & 22.1 & 5.2 & 162.9 & 41.8 \\
\hline Quartile 3 & 154.9 & 52.0 & 76.6 & 34.4 & 83.8 & 330.9 & 59.5 & 12.1 & 217.1 & 79.8 \\
\hline Max & 281.5 & 37.4 & 230.3 & 220.5 & 202.0 & 519.0 & 17.6 & 63.1 & 560.1 & 341.5 \\
\hline Mean & 125.1 & 35.2 & 56.8 & 33.1 & 65.4 & 249.5 & 34.9 & 10.2 & 168.2 & 68.6 \\
\hline Std. Dev. & 55.0 & 29.1 & 48.6 & 40.3 & 45.2 & 130.1 & 37.1 & 14.5 & 97.9 & 72.2 \\
\hline \multicolumn{11}{|c|}{ 1950-1995 Subsample } \\
\hline Min & 21.0 & 0.1 & 10.0 & 2.3 & 2.0 & 7.0 & 0.0 & 0.0 & 34.3 & 2.2 \\
\hline Quartile 1 & 93.0 & 10.8 & 32.5 & 13.6 & 25.9 & 155.5 & 9.8 & 2.0 & 82.3 & 26.0 \\
\hline Median & 106.9 & 25.0 & 52.8 & 20.0 & 42.7 & 272.6 & 33.5 & 5.9 & 127.1 & 49.0 \\
\hline Quartile 3 & 136.5 & 52.7 & 82.3 & 45.2 & 70.2 & 329.7 & 63.9 & 16.0 & 179.6 & 88.7 \\
\hline Max & 281.5 & 137.4 & 230.3 & 220.5 & 127.9 & 519.0 & 217.6 & 63.1 & 560.1 & 341.5 \\
\hline Mean & 116.5 & 34.0 & 67.4 & 37.9 & 50.6 & 251.6 & 40.6 & 12.2 & 137.9 & 76.3 \\
\hline Std. Dev. & 51.1 & 31.4 & 50.7 & 44.6 & 32.5 & 133.2 & 39.9 & 15.9 & 87.9 & 80.3 \\
\hline \multicolumn{11}{|c|}{ 1996-2009 Subsample } \\
\hline Min & 59.5 & 11.3 & 9.2 & 6.0 & 67.8 & 20.5 & 2.2 & 0.4 & 181.0 & 24.1 \\
\hline Quartile 1 & 115.4 & 23.4 & 14.6 & 8.0 & 74.3 & 190.7 & 5.4 & 0.9 & 224.7 & 30.7 \\
\hline Median & 144.0 & 37.3 & 21.1 & 15.4 & 93.4 & 226.8 & 12.4 & 2.4 & 264.0 & 34.5 \\
\hline Quartile 3 & 193.2 & 51.4 & 25.3 & 22.9 & 161.6 & 331.9 & 21.0 & 3.2 & 314.1 & 49.6 \\
\hline Max & 279.1 & 81.6 & 48.1 & 44.4 & 202.0 & 426.8 & 59.0 & 15.9 & 341.0 & 93.5 \\
\hline Mean & 153.2 & 39.1 & 21.9 & 17.3 & 114.2 & 242.6 & 16.2 & 3.4 & 267.8 & 43.0 \\
\hline Std. Dev. & 59.6 & 20.4 & 10.4 & 11.5 & 47.9 & 123.9 & 15.6 & 4.1 & 53.3 & 20.8 \\
\hline \multicolumn{11}{|c|}{ Regression Results } \\
\hline Constant & $\begin{array}{c}72.31 \\
(107.10)^{2} \\
\end{array}$ & $\begin{array}{c}-3.82 \\
(60.95) \\
\end{array}$ & $\begin{array}{c}-122.69^{*} 1 \\
(167.88) \\
\end{array}$ & \begin{tabular}{l|l}
1 & -129.64 \\
& $(153.80)$
\end{tabular} & $\begin{array}{c}39.74 \\
(62.12) \\
\end{array}$ & $\begin{array}{l}854.44^{* *} \\
(843.20)\end{array}$ & $\begin{array}{r}-36.64 \\
(95.41) \\
\end{array}$ & \begin{tabular}{|c}
$-47.29^{* *}$ \\
$(66.28)$ \\
\end{tabular} & $\begin{array}{r}187.40 \\
(247.73) \\
\end{array}$ & $\begin{array}{c}157.49 \\
(168.79) \\
\end{array}$ \\
\hline Trend & $\begin{array}{l}1.98^{* *} \\
(2.04)\end{array}$ & $\begin{array}{l}1.09^{* *} \\
(1.34)\end{array}$ & $\begin{array}{l}2.24^{* *} \\
(2.75)\end{array}$ & $\begin{array}{c}1.60 \\
(1.90) \\
\end{array}$ & $\begin{array}{l}1.15^{* *} \\
(1.43)\end{array}$ & $\begin{array}{c}-5.39^{* *} \\
(5.60)\end{array}$ & $\begin{array}{c}0.27 \\
(1.22) \\
\end{array}$ & $\begin{array}{l}0.68^{*} \\
(0.87)\end{array}$ & $\begin{array}{c}0.86 \\
(2.32) \\
\end{array}$ & $\begin{array}{l}-0.67 \\
(1.57)\end{array}$ \\
\hline FAIR & $\begin{array}{l}-23.51 \\
(32.92) \\
\end{array}$ & $\begin{array}{l}-22.39^{* *} \\
(26.92)\end{array}$ & $\begin{array}{c}-55.78^{* *} \\
(60.39) \\
\end{array}$ & $\begin{array}{l}-14.61 \\
(19.10) \\
\end{array}$ & $\begin{array}{c}22.48 \\
(28.50) \\
\end{array}$ & $\begin{array}{l}-44.59 \\
(77.99) \\
\end{array}$ & $\begin{array}{c}-3.24 \\
(18.30) \\
\end{array}$ & $\begin{array}{c}-11.17^{* *} \\
(13.32) \\
\end{array}$ & $\begin{array}{r}75.30 \\
(95.59) \\
\end{array}$ & $\begin{array}{l}-40.35 \\
(54.00) \\
\end{array}$ \\
\hline \multirow[t]{2}{*}{$\begin{array}{c}\text { Prices } \\
\text { Received }\end{array}$} & -0.01 & 0.06 & $0.71^{* *}$ & $0.67^{* *}$ & -0.08 & $-2.46^{* *}$ & 0.37 & $0.23^{* * *}$ & -0.36 & -0.34 \\
\hline & $(0.28)$ & $(0.24)$ & $(0.86)$ & $(0.75)$ & $(0.21)$ & $(2.43)$ & $(0.50)$ & $(0.30)$ & $(0.65)$ & $(0.42)$ \\
\hline
\end{tabular}

$1{ }^{* *}$ and $*$ denotes statistical significance at the 0.05 and 0.10 levels of confidence. Statistical significance levels are computed using Jackknifing.

2. Numbers in parenthesis denote standard error, computed through jackknifing.

\subsection{Aggregate Inequalities}

Table 3 presents the aggregate measures of the inequality between the distributions of farmland values and government payments. The total inequality measure is relatively stable until 1976 when it increases from 169.0 in 1975 to 333.4. It then stays relatively high through 2001. The decomposition 
indicates that the variation in information is largely due to changes in the inequality between regions (as depicted in column 2).

Table 3. Aggregate inequality $(\times 1,000)$ between land values and government payments.

\begin{tabular}{|c|c|c|c|}
\hline Year & Regional Inequality & Average Inequality & Total Inequality \\
\hline 1950 & 68.7 & 35.9 & 104.4 \\
\hline 1951 & 58.2 & 37.6 & 95.6 \\
\hline 1952 & 44.9 & 50.6 & 95.1 \\
\hline 1953 & 43.0 & 54.4 & 96.8 \\
\hline 1954 & 57.7 & 42.0 & 100.1 \\
\hline 1955 & 92.2 & 65.7 & 157.2 \\
\hline 1956 & 79.6 & 62.0 & 141.8 \\
\hline 1957 & 114.3 & 54.4 & 169.4 \\
\hline 1958 & 134.2 & 74.0 & 208.9 \\
\hline 1959 & 90.6 & 87.2 & 177.8 \\
\hline 1960 & 92.7 & 97.5 & 190.1 \\
\hline 1961 & 134.2 & 62.3 & 197.0 \\
\hline 1962 & 118.7 & 81.5 & 200.9 \\
\hline 1963 & 137.3 & 68.2 & 206.1 \\
\hline 1964 & 157.2 & 103.3 & 261.3 \\
\hline 1965 & 150.6 & 95.5 & 246.8 \\
\hline 1966 & 99.5 & 72.0 & 172.5 \\
\hline 1967 & 104.1 & 68.8 & 173.8 \\
\hline 1968 & 84.7 & 57.0 & 142.7 \\
\hline 1969 & 74.4 & 52.4 & 128.0 \\
\hline 1970 & 84.5 & 55.7 & 141.4 \\
\hline 1971 & 102.8 & 55.2 & 159.6 \\
\hline 1972 & 103.0 & 57.5 & 162.2 \\
\hline 1973 & 92.0 & 55.4 & 149.7 \\
\hline 1974 & 95.4 & 70.6 & 165.7 \\
\hline 1975 & 110.2 & 58.8 & 169.0 \\
\hline 1976 & 196.7 & 136.8 & 333.4 \\
\hline 1977 & 250.6 & 100.0 & 351.1 \\
\hline 1978 & 188.3 & 117.0 & 306.0 \\
\hline 1979 & 248.6 & 71.6 & 320.5 \\
\hline 1980 & 216.9 & 149.0 & 366.1 \\
\hline 1981 & 235.7 & 138.3 & 374.5 \\
\hline 1982 & 204.5 & 72.8 & 278.3 \\
\hline 1983 & 148.5 & 73.1 & 223.5 \\
\hline 1984 & 81.7 & 40.1 & 123.0 \\
\hline 1985 & 150.7 & 58.5 & 211.2 \\
\hline 1986 & 176.2 & 92.3 & 270.9 \\
\hline 1987 & 193.4 & 98.0 & 294.8 \\
\hline 1988 & 202.7 & 92.4 & 299.2 \\
\hline 1989 & 149.0 & 68.6 & 220.7 \\
\hline 1990 & 178.5 & 89.7 & 271.2 \\
\hline
\end{tabular}


Table 3. Cont.

\begin{tabular}{|c|c|c|c|}
\hline Year & Regional Inequality & Average Inequality & Total Inequality \\
\hline 1991 & 189.5 & 90.6 & 282.9 \\
1992 & 147.3 & 66.3 & 216.4 \\
1993 & 181.5 & 62.2 & 246.7 \\
1994 & 155.3 & 93.3 & 251.0 \\
1995 & 193.7 & 102.6 & 298.5 \\
1996 & 152.5 & 86.3 & 241.1 \\
1997 & 164.3 & 98.9 & 265.6 \\
1998 & 172.3 & 108.6 & 283.0 \\
1999 & 177.7 & 87.7 & 267.2 \\
2000 & 151.1 & 87.1 & 239.9 \\
2001 & 164.9 & 87.7 & 254.7 \\
2002 & 80.6 & 89.2 & 171.2 \\
2003 & 114.0 & 62.9 & 178.3 \\
2004 & 130.7 & 66.3 & 198.5 \\
2005 & 142.2 & 83.6 & 227.3 \\
2006 & 122.1 & 79.7 & 202.8 \\
2007 & 116.5 & 75.3 & 192.9 \\
2008 & 84.0 & 78.8 & 163.5 \\
2009 & 70.1 & 78.7 & 149.3 \\
\hline
\end{tabular}

Table 4 presents the ordinary least squares (again using jackknifing to correct for non-normaility and hetroscedasticity in the data) results for the linear specification in Equation (8) applied to the aggregate information measures.

Table 4. Aggregate inequality between land values and government payments.

\begin{tabular}{|c|c|c|c|}
\hline Year & Regional Inequality & Average Inequality & Total Inequality \\
\hline Constant & $96.45^{1}$ & $46.43^{*}$ & 147.00 \\
& $(111.59)^{2}$ & $(69.16)$ & $(177.80)$ \\
\hline \multirow{2}{*}{ Trend } & $2.34^{* *}$ & $0.85^{* *}$ & $3.21^{* *}$ \\
& $(2.63)$ & $(0.84)$ & $(3.89)$ \\
\hline FAIR & $-80.54^{* *}$ & -13.86 & $-95.72^{* *}$ \\
& $(87.00)$ & $(16.07)$ & $(99.05)$ \\
\hline Prices Received & -0.08 & 0.05 & -0.05 \\
\hline & $(0.27)$ & $(0.14)$ & $(0.46)$ \\
\hline
\end{tabular}

1. ${ }^{* *}$ and $*$ denotes statistical significance at the 0.05 and 0.10 levels of confidence, respectively. Statistical significance levels are computed using Jackknifing

2. Numbers in parenthesis denote standard error, computed using Jackknifing.

The results indicate that the FAIR dummy is statistically significant for the regional inequality measure (i.e., the inequality measure between regions) and not for the average inequality measure across all regions. Hence, the results support the contention that the implementation of FAIR has significantly affected the relationship between the share of farmland values and the share of 
government payments between regions. However, the results indicate that distribution of farmland values has become more like the distribution of government payments. Results from this study are consistent with the findings in recent literature [36,37].

\section{Conclusions}

The passage of the Federal Agricultural Improvement and Reform (FAIR) Act of 1996 was touted as a major move toward a market-oriented agricultural policy. A significant plank in this contention was that production decisions would be largely decoupled from government programs by the move to Agricultural Market Transition Assistance (AMTA) payments. The effect of the shift in agricultural policy on farmland valuation, however, was somewhat more ambiguous. The decoupling of production decisions from government policies would reduce the linkage between agricultural policies and cash flows to farmland from operations, but AMTAs and other direct payments were still distributed based on the base production from pre-FAIR agricultural programs. More recent programs such as the Food Security and Rural Investment (FSRI) Act of 2002 and the Food, Conservation, and Energy (FCE) Act of 2008 contain provisions for Countercyclical payments which are based on the same base acreages and established yields. To analyze these competing forces, this study computes an information measure to analyze the divergence between farmland values and direct government payments and then estimates whether the implementation of FAIR is statistically significant in explaining movements in this informational metric over time. The results indicate that FAIR is associated with a significant decline in the inequality between farmland values and government payments for the Northeast, Lake States, Corn Belt, and Southern Plains, but is associated with an increase in the inequality for Mountain region.

To further investigate the effect of FAIR on the relationship between farmland values and government payments, the study then examines the effect of the FAIR on aggregate information measures. These results indicate that FAIR is significant in explaining the variation in regional inequality. Hence, the introduction of FAIR has reduced the dispersion between farmland values and government payments between regions. The numeric results indicate that the introduction of FAIR is actually associated with the dispersion of farmland values becoming more like the distribution of direct government payments. This may actually be the result of an increased certainty of direct government transfers under FAIR, FSRI, and FCE.

\section{Acknowledgements}

We are indebted to the editor and reviewers for helpful comments and suggestions. The views expressed in this manuscript represent those of the authors and do not necessarily represent those of the USDA. This project was supported by the USDA Cooperative State Research Education \& Extension Service, Hatch project \# 0212495 and Louisiana State University Experiment Station project \# LAB 93872. 


\section{References}

1. Theil, H. Economics and Information Theory; North-Holland Publishing Co.: Amsterdam, The Netherlands, 1967.

2. Schmitz, A.; Moss, C.B.; Schmitz, T.G.; Furtan, H.W.; Schmitz, H.C. Agricultural Policy, Agribusiness, and Rent-Seeking Behaviour; University of Toronto Press: Toronto, ON, Canada, 2010.

3. Moss, C.B.; Schmitz, A. Government Policy and Farmland Markets: The Maintenance of Farmer Wealth; Iowa State University Press: Ames, IA, USA, 2003.

4. Reynolds, J.E.; Timmons, J.F. Factors Affecting Farmland Values in the United States; Research Bulletin No. 566; Iowa State University Agricultural Experiment Station: Ames, IA, USA, 1969.

5. Duffy, P.A.; Taylor, C.R.; Casin, D.L; Young, G.L. The Economic Value of Farm Program Base. Land Econ. 1994, 70, 318-329.

6. Harris, D.G. Inflation-Indexes, Price Supports, and Land Values. Am. J. Agr. Econ. 1977, 59, 489-495.

7. Herriges, D.H.; Barikman, N.E.; Shogren, J.F. The Implicit Value of Corn Base Acreage. Am. J. Agr. Econ.1992, 74, 50-58.

8. Barnard, C.; Nehring, R.; Ryan, J.; Collender, R. Higher Cropland Value from Farm Program Payments: Who Gains. Agr. Outlook 2001, November, 26-30.

9. Gardner, B.L. U.S. Commodity Policies and Land Prices; Technical Report WP 02-02; University of Maryland: College Park, MD, USA, 2002.

10. Weersink, A.; Clark, S.; Turvey, C.G.; Sarker, R. The Effect of Agricultural Policy on Farmland Values. Land Econ. 1999, 75, 425-439.

11. Shaik, S.; Atwood, J.A.; Helmers, G.A. The Evolution of Farm Programs and their Contribution to Agricultural Land Values. Am. J. Agr. Econ. 2005, 87, 1190-1197.

12. Mason, J.E. Acreage Allotments and Land Prices. J. Land Public Utility Econ. 1968, 22, 176-181.

13. Seagraves, J.A. Capitalized Values of Tobacco Allotments and the Rate of Return to Allotment Holders. Am. J. Agr. Econ. 1969, 51, 320-334.

14. Tweeten, L.; Martin, J.E. A Methodology for Predicting U.S. Farm Real Estate Price Variations. J. Farm Econ. 1976, 42, 378-393.

15. Herdt, R.; Cochrane. W. Farm Land Prices and Farm Technology Advance. J. Farm Econ. 1966, 48, 243-263.

16. Melichar, E. Capital Gains versus Current Income in the Farming Sector. Am. J. Agr. Econ. 1979, 61, 1086-1106.

17. Traill, W.B. Land Values and Rents: The Gains and Losses from Farm Price Support Programmes; Department of Agricultural Economics Bulletin No. 175; University of Manchester: Manchester, UK, 1980.

18. Clark, J.S.; Klein, K.K.; Thompson, S.J. Are Subsidies Capitalized into Land Values? Some Time Series Evidence from Saskatchewan. Can. J. Agr. Econ. 1993, 41, 55-163.

19. Just, R.E.; Miranowski, J.A. Understanding Farmland Price Changes. Am. J. Agr. Econ. 1993, 75, $156-168$. 
20. Moss, C.B.; Shonkwiler, J.S.; Reynolds, J.E. Government Payments to Farmers and Real Agricultural Asset Values in the 1980s. South. J. Agr. Econ. 1989, 21, 139-153.

21. Featherstone, A.M.; Baker, T.G. Effects of Reduced Price and Income Supports on Farmland Rents and Values. NC J. Agr. Econ. 1988, 10, 177-190.

22. Alston, J.M. An Analysis of Growth of U.S. Farmland Prices, 1963-1982. Am. J. Agr. Econ. 1986, 68, 1-9.

23. Burt, O.R. Econometric Modeling of the Capitalization Formula for Farmland Prices. Am. J. Agr. Econ. 1986, 68, 10-26.

24. Pope, R.D.; Kramer, R.A.; Green, R.D.; Gardner, B.D. An Evaluation of Economic Models of U.S. Farmland Prices. West. J. Agr. Econ. 1978, 4, 107-119.

25. Palmquist, R.B.; Danielson, L.E. A Hedonic Study of the Effects of Erosion Control and Drainage on Farmland Values. Am. J. Agr. Econ. 1989, 71, 55-62.

26. Shonkwiler, J.S.; Reynolds, J.E. A Note of the Use of Hedonic Price Models in the Analysis of Land Prices at the Urban Fringe. Am. J. Agr. Econ. 1986, 69, 58-63.

27. Xu, F.; Mittelhammer, R.C.; Barkley, P.W. Measuring the Contributions of Site Characteristics to the Value of Agricultural Land. Land Econ. 1993, 69, 356-369.

28. Goodwin, B.K.; Ortalo-Magne, F.N. The Capitalization of Wheat Subsidies into Agricultural Land Values. Can. J. Agr. Econ. 1992, 40, 37-54.

29. Goodwin, B.K.; Mishra, A.K.; Ortalo-Magne, F.N. What's Wrong with Our Models of Agricultural Land Values. Am. J. Agr. Econ. 2003, 85, 744-752.

30. Vantreese, V.L.; Reed, M.R.; Skees, J.R. Production Controls and Asset Values. Am. J. Agr. Econ. 1989, 71, 319-325.

31. Moss, C.B. Returns, Interest Rates, and Inflation: How They Explain Changes in Farmland Values. Am. J. Agr. Econ. 1997, 79, 1311-1318.

32. Lindon, J.R.; Lins, D.A.; Venkataraman, R. Cash Rents and Land Values in U.S. Agriculture. Am. J. Agr. Econ. 1985, 67, 794-805.

33. Shaik, S. Farm Programs and Land Values in Mountain States: Alternative Panel Estimators. In Proceedings of the WAEA Annual Meetings, Portland, OR, USA, 29 July 2007.

34. Falk, B. Formally Testing the Present Value Model of Farmland Prices. Am. J. Agr. Econ. 1991, 73, 1-10.

35. Lence, S.H.; Mishra, A.K. The Impacts of Different Farm Programs on Cash Rents. Am. J. Agr. Econ. 2003, 85, 753-761.

36. Shaik, S.; Miljkovic, D. Dynamic Relationships Between Farm Real Estate Values and Federal Farm Program Payments. J. Agr. Resour. Econ. 2010, 35, 153-165.

37. Goodwin, B.K.; Mishra, A.K.; Ortalo-Magne, F.N. The Buck Stops Where? The Distribution of Agricultural Subsidies; NBER Working Paper 16693; National Bureau of Economic Research: Cambridge, MA, USA, 2011.

38. USDA/NASS. Land Values and Cash Rents. United States Deparment of Agriculture, Washington, DC, USA, 2010.

39. USDA/NASS. Data and Statistics: Quickstats. United States Department of Agriculture, Washington, DC, USA, 2010. 
40. Theil, H.; Chung, C.-F.; Seale, J.L., Jr. International Evidence on Consumption Patterns; JAI Press: Greenwich, CT, USA, 1989.

41. Efron, B. Bootstrap Methods: Another Look at the Jackknife. Ann. Statist. 1979, 7, 1-26.

42. Efron, B. Nonparametric Estimates of Standard Error: The Jackknife, the Bootstrap, and Other Methods. Biometrika 1981, 68, 589-599.

(C) 2011 by the authors; licensee MDPI, Basel, Switzerland. This article is an open access article distributed under the terms and conditions of the Creative Commons Attribution license (http://creativecommons.org/licenses/by/3.0/). 